\title{
Emergence and Initial Growth of the Seedlings of Euterpe oleracea Mart. Seeds of Different Ecotypes in Function on the Substrate
}

\author{
S. A. Silva ${ }^{1}$, P. A. F. R. Melo ${ }^{1}$, J. R. G. Araújo ${ }^{1}$, J. J. A. Gomes ${ }^{1}$, T. F. Jesus ${ }^{1}$, A. C. V. Neves Junior ${ }^{1}$, \\ F. A. Santos ${ }^{1}$, R. N. S. Lemos ${ }^{1} \&$ J. M. Mondego ${ }^{1}$ \\ ${ }^{1}$ Center of Agricultural Sciences, State University of Maranhão, São Luís, MA, Brazil \\ Correspondence: P. A. F. R. Melo, Foundation for Scientific Research and Development of Maranhão and \\ Postgraduate Program in Agroecology, Center of Agricultural Sciences, State University of Maranhão, Cidade \\ Universitária Paulo VI, S/N, 65.055-098, São Luís, Brazil. Tel: 55-16-981-018-277. E-mail: \\ pauloalexandrefernandes@outlook.com
}

\author{
Received: July 7, $2018 \quad$ Accepted: August 9, $2018 \quad$ Online Published: September 15, 2018 \\ doi:10.5539/jas.v10n10p325 URL: https://doi.org/10.5539/jas.v10n10p325
}

\begin{abstract}
In Brazil, the assai (Euterpe oleracea Mart.) is a native palm of the Amazon biome, being exploited in an extractive and predatory way to obtain palm heart and processed pulp. In recent years, there has been an increase in the exploitation of commercial plantations in the country, since extractivism and management of native areas are not able to meet growing demand. In this way, companies of the sector and public institutions have invested in new technologies, such as the improvement of plants, which has increased the demand for good quality seeds, coming from natural ecotypes. Thus, the objective of this work was to evaluate seeds of E. oleracea from three ecotypes regarding the emergence and initial growth of the seedlings in different substrates to guide future plant selection. Seed lots from three assai berry ecotypes were evaluated for water content, seedling emergence, first count, seedling emergence speed index, seedling length and dry mass. The experimental design was completely randomized, with four repetitions of 50 seeds, sown on different substrates. In the physiological characteristics of the seeds and seedlings, there are differences of the three E. oleracea ecotypes. These ecotypes make it possible to identify and select assai palm's mother plants of Luiz Domingues (IG) and Maracanã (V) natives of areas of the igapó and várzea, respectively, as producers of better quality seeds and seedlings in an alternative substrate (composed of sand, agricultural soil and cattle manure in a proportion of 2:2:1) and, commercial substrate (FORTH ${ }^{\circledR}$ compound of pinus and gray bark), respectively.
\end{abstract}

Keywords: Assai fruits, native species, seedling production, vigor.

\section{Introduction}

In Brazil, the assai (Euterpe oleracea Mart.) is a native palm from Amazon biome, occurring in the states of Pará, Amazonas, Maranhão and Amapá, extending to the Guianas, Venezuela and Colombia (Garzón et al., 2017). This species is typical of terra firme, várzea and igapó forests, being exploited in an extractive and predatory way to obtain palm heart and processed pulp. The diversity of natural populations of E. oleracea is potentiated by their occurrence in different environments, thus characterized: Igapó-areas of forest that remain permanently flooded after floods with rains and/or river waters; Várzea-terraces or forest areas flooded seasonally with river and/or rainfall waters and, Terra Firme-non-flooded areas, plateaus (Oliveira et al., 2016).

In the 1960s, the production of Brazilian palm heart came from the Southeastern Region, being extracted from the juçara palm (Euterpe edulis Mart.) from the Atlantic Forest (Barroso et al., 2010). However, uncontrolled exploitation without corresponding replanting and adequate management reduced the number of palm trees in this region, stimulating the transfer of the palm heart processing companies to the State of Pará, with extensive reserves of assai palm's (Martins et al., 2009).

On the other hand, in recent years, there has been an increase in the commercial exploitation of cash crops in Brazil, accounting for around 136 thousand hectares of areas planted with assai palm's, since extractivism and the management of native areas are not capable to meet growing demand. Thus, companies in the industry and public institutions have invested in new technologies, such as plant breeding, including the selection of regional ecotypes, to be used for this purpose (Paniagua-Zambrana et al., 2017). In this way, the demand for good quality 
seeds, from natural populations (ecotypes), destined to the rational cultivation, increased, so that the implementation of programs of improvement and recomposition of native forests (Oliveira et al., 2016).

Considering that E. oleracea presents a wide geographic distribution in Brazil, it is expected that genetic and phenotypic diversity occur among native ecotypes (Oliveira et al., 2016). These differences are distinguished as regards biochemical, morphological and physiological characteristics of fruits and seeds (Wycoffet al., 2015). Seeds formed under flood stress in várzeas and igapós, for example, may undergo alterations in their composition, quantity, reserve mobilization and germination enzymes, which may affect seedling growth and the production of seedlings of assai (Gonçalves et al., 2010). Thus, the selection of individuals with desirable performance characteristics can be performed in advance, based on the physiological potential of the seeds, emergence and vigor of the seedlings (Martins et al., 2013).

The physiological quality of the seeds has been characterized by germination, conducted under ideal conditions of temperature and substrate in a laboratory environment (Brasil, 2009), although there are still no federal standards that establish the limits of this attribute for assai seeds as occur in other species. When these conditions are not verified at seedling production sites, divergences may occur with respect to laboratory results (Martins et al., 2007). Thus, predicting field performance is an important objective in the selection of seed lots, with the potential to germinate, emerge and rapidly result in normal seedlings (Marcos Filho, 2015).

In addition to all that has already been mentioned, one of the greatest obstacles in the production of palm trees is the cultivation from seeds, due to the low germinative power and the excessively long time for their germination, characteristically uneven (Corder \& Saldanha, 2006). The viable seeds initiate the germination process on average in periods ranging from 60 days to 170 days after sowing. The implantation of the palm heart production system, properly managed, must be fully viable and sustainable from an ecological, social and economic point of view. Thus, based on current legislation and aiming to regulate production, we must adopt elaborate criteria of studies on the ecology of the species, in order to create a sustainable management plan that must be submitted to the licensing body. Therefore, regardless of the form of propagation chosen for the formation of plants, it is important to choose the appropriate substrate (Brahmet al., 2013).

In studies on the physiological potential in seeds of different $E$. edulis ecotypes, it was observed distinct times of seedling permanence in the early stages of development and the delay in emerging from the substrate, impairing the operations in the seedling nursery. Therefore, seed lots are preferred, not only with high germination rate, but with vigorous seedlings in height, neck diameter and number of leaves. In addition, the choice of substrate is also important, as it provides moisture and adequate conditions for seedling germination and development (Martins-Corder \& Saldanha, 2006).

Considering the above, the objective of this work was to evaluate E. oleracea seeds from three ecotypes, regarding the emergence and initial growth of the seedlings in different substrates to guide future selections of parent plants.

\section{Material and Methods}

Mature fruits of three ecotypes of E. oleracea Mart. were collected manually in ten assai palm's mother plants preselected for each of these natural populations, in the month of December, 2016. The fruits were from the Maracanã (V) and Luís Domingues (IG) ecotypes, collected in the várzea and igapó environment directly from the occurrence areas of Luís Domingues do Maranhão and São Luís, county of the State of Maranhão, Brazil, respectively. Also, the ecotype Luis Domingues (TF), originating from plants cultivated on land, was explored from an Agroforestry System (AFS) with 'cupuaçu' (Theobroma grandiflorum (Willd. Ex Spreng.) K. Schum. This AFS belonged to the Experimental Farm of the Center of Agricultural Sciences of the State University of Maranhão, Campus of São Luís, MA, Brazil, managed in clumps and with eight years of age (Table 1). 
Table 1. Description of seed lots of E. oleracea, as to the origin and geographical and climatological information of these sites. São Luís, MA, Brazil, 2018

\begin{tabular}{llllll}
\hline *Ecotypes & Environment & Latitude (S) & Longitude (W) & Climate** & Precipitation (mm) \\
\hline Maracanã (V) & Várzea & $02^{\circ} 31^{\prime} 47^{\prime \prime}$ & $44^{\circ} 18^{\prime} 10^{\prime \prime}$ & Aw & 1.896 \\
Luís Domingues (IG) & Igapó & $01^{\circ} 16^{\prime} 06^{\prime \prime}$ & $45^{\circ} 52^{\prime} 24^{\prime \prime}$ & Aw & 2.278 \\
Luís Domingues (TF) & Terra Firme & $02^{\circ} 31^{\prime} 47^{\prime \prime}$ & $44^{\circ} 18^{\prime} 10^{\prime \prime}$ & Aw & 1.896 \\
\hline
\end{tabular}

Note. * Maracanã (V): Assai palms of várzea are natives of areas of Amazonian forest flooded seasonally with rains and/or river waters. Várzea is also used to describe the flood plain forests which are flooded; Luís Domingues (IG): Assai palm of igapó are natives of area of forest that remain permanently flooded after the floods with the rains and/or waters of the rivers; Luís Domingues (TF): Assai palm of terra firme refers to lower elevation Amazonian rain forest growing on higher, solid ground that does not flood.

** Classification according to Köppen and Geiger (1928). Source: http://pt.climate-data.org/country/114

Aw (tropical savannah climate with dry winter season), with average temperature in any month of the year exceeding $18{ }^{\circ} \mathrm{C}$. Winter is dry, with average rainfall less than $60 \mathrm{~mm}$ in at least one of the months of this season.

After harvesting, the fruits were packed in nylon bags and taken to the Laboratory of Phytotechnology and Post-Harvest. In the laboratory, the fruits were washed and immersed in water at $40 \pm 3{ }^{\circ} \mathrm{C}$, for 20 minutes, to facilitate the softening of the bark and removal of the pulp in a mechanical pulper. The seeds were washed to remove the residues and placed on tower paper in a laboratory environment at $25 \pm 3{ }^{\circ} \mathrm{C}$ for 48 hours. After this period, the water content was determined by the greenhouse method at $105 \pm 3{ }^{\circ} \mathrm{C}$, for 24 hours (Brasil 2009), using three repetitions of 25 seeds.

The experiment was carried out in the greenhouse of Experimental Farm of the Center of Agricultural Sciences of the State University of Maranhão, São Luís, MA, Brazil, from December 2016 to February 2017, in order to carry out the following tests and determinations:

(1) First Count Emergence: performed in conjunction with the emergence test, calculating the average number of seeds germinated on the 20th day after sowing and expressing the data as percentage.

(2) Seedling Emergence Test: with four repetitions of 50 seeds of each ecotype, seeded at two centimeters depth in plastic trays $(49 \times 30 \times 10 \mathrm{~cm})$, containing an alternative substrate that was composed of a mixture of sand, agricultural soil and cattle manure in the proportion of 2:2:1 $\left(\mathrm{S}_{1}\right)$. The second substrate used was FORTH ${ }^{\circledR}$ commercial substrate composed of decomposed pinus peel and gray $\left(\mathrm{S}_{2}\right)$, moistened and kept at room temperature $\left(25 \pm 3{ }^{\circ} \mathrm{C}\right.$ and $\mathrm{RH}$ of $\left.80 \pm 4 \%\right)$. The maintenance of humidity was carried out by means of daily watering; counting the percentage of seedlings emerged from the $20^{\text {th }}$ and the $64^{\text {th }}$ days after sowing, when the stabilization of the emergence was verified.

(3) Speed of Emergence Index: conducted together with the seedling emergence test, from the $20^{\text {th }}$ to the $64^{\text {th }}$ day after sowing, computing the number of seedlings emerged per day and applying the formula proposed by Maguire, (1962).

(4) Evaluation of Seedling Development: evaluated at the end of the seedling emergence test by measuring the length of the aerial part and the primary root of the seedlings, using a ruler graduated in centimeters, calculating the average length per seedling in each repetitions replicate $\left(\mathrm{cm}\right.$ seedling $\left.{ }^{-1}\right)$. After measurements, the seedlings were weighed using a scale with an accuracy of $0.001 \mathrm{~g}$, and recorded their fresh mass; were then placed in a forced air circulation oven at $65 \pm 3{ }^{\circ} \mathrm{C}$, for 48 hours. After this period, the samples were placed to cool in desiccator and then weighed in an analytical balance with an accuracy of $0.0001 \mathrm{~g}$, the results of which were expressed in g seedling $^{-1}$ (Nakagawa, 1999).

The experimental design was completely randomized, with treatments arranged in a with $3 \times 2$ factorial, the first factor represented by the ecotypes ['Maracanã (V)', 'Luis Domingues (IG)' and 'Luis Domingues (TF)'] and the second by the substrates (alternative substrate and FORTH ${ }^{\circledR}$ commercial substrate), with four repetitions. In the statistical analysis, the seedling emergence percentage (\%) data were transformed according to the equation $\arcsin \sqrt{x}$. All data were submitted to analysis of variance by the F test, with the means compared by the Tukey's test, at the $5 \%$ probability level and the software Assistat. 


\section{Results and Discussion}

The water content of the seed lots of E. oleracea was between 21.57 and $28.0 \%$, depending on the ecotype (data not shown in the tables). These differences were possibly due to the uneven maturity of the seeds in the bunch and the thickness of the endocarp. Results similar to those found in this study were verified for water content in seeds of other palm species, with a low domestication rate and a different genetic profile. This fact was recurrent even in cases where fruits were harvested with uniform coloration, such as those obtained in seed lots of Archontophoenix cunninghamiana H. Wendl. \& Drude (Martins et al., 2013) and Astrocaryum aculeatum G. Mey (Ramos et al., 2011).

In the first count emergence (FCE), was verified that the highest percentages of emerged seedlings, at 20 days after sowing, were 12.01 and $8.98 \%$ for Luís Domingues (IG) assai seeds, regardless of the substrate evaluated, although not statistically different for FCE of Luís Domingues (TF) $(6.09 \%)$ assai seeds evaluated on commercial substrate $\left(\mathrm{S}_{2}\right)$ (Table 2). Evaluating the seedling emergence (SE\%), at 64 days after sowing, the most relevant percentages among the E. oleracea ecotypes studied are associated once more with the assai seed lot Luís Domingues (IG), seeded on both substrates, not differing from seedlings emerged from the Maracanã (V) assai seeds on alternative substrate $\left(\mathrm{S}_{1}\right)$. For the speed of emergence index (SEI), there was no significant difference between treatments when compared by the Tukey's test at the $5 \%$ probability level (Table 2 ).

Results similar to those presented here were reported by Beckmann et al. (2012), evaluating the physiological potential of E. oleracea seeds, scarified, where these authors demonstrated that the highest percentage of vigorous seedlings was obtained using the mixture of soil and cattle manure. The results obtained in this study (Table 2) are consistent with those reported by Gonçalves et al. (2010), studying the physiology of germination of this same species, verified that seeds harvested in flooded areas presented higher rates for the first count and percentage of germination when compared to seeds coming from uplands. Probably the best physiological potential of assai seeds developed in flooded environments, such as igapó where the highest content of organic matter and nutrients, is due to the cycling of organic material accumulated in the forest soil due to flooding with rainwater and/or rivers.

Table 2. First Count Emergence (FCE), Seedling Emergence (SE\%) and Speed of Emergence Index (SEI) of $E$. oleracea from three ecotype seeds. São Luis, MA, Brazil, 2018 under two different substrates

\begin{tabular}{|c|c|c|c|c|c|c|}
\hline \multirow{2}{*}{ *Ecotypes } & \multicolumn{2}{|c|}{ FCE } & \multicolumn{2}{|c|}{$\mathrm{SE} \%$} & \multicolumn{2}{|c|}{ SEI } \\
\hline & $* * \mathrm{~S}_{1}$ & $\mathrm{~S}_{2}$ & $\mathrm{~S}_{1}$ & $\mathrm{~S}_{2}$ & $\mathrm{~S}_{1}$ & $\mathrm{~S}_{2}$ \\
\hline Luís Domingues (IG) & $12.01 \mathrm{aA}$ & $8.98 \mathrm{aA}$ & $61.12 \mathrm{aA}$ & $56.82 \mathrm{aA}$ & $14.61 \mathrm{aA}$ & $10.69 \mathrm{aA}$ \\
\hline Maracanã (V) & $6.09 \mathrm{bA}$ & $0 \mathrm{bB}$ & $65.32 \mathrm{aA}$ & $52.63 \mathrm{aB}$ & $11.46 \mathrm{aA}$ & $8.42 \mathrm{aA}$ \\
\hline Luís Domingues (TF) & $4.06 \mathrm{bA}$ & $6.09 \mathrm{aA}$ & $44.71 \mathrm{bA}$ & $43.27 \mathrm{bA}$ & $8.94 \mathrm{aA}$ & $8.54 \mathrm{aA}$ \\
\hline C.V. $(\%)$ & 6.65 & & 6.49 & & 11.06 & \\
\hline
\end{tabular}

Note. Means followed by the same lowercase letters in the column and upper case in the row do not differ from each other by the Tukey's test at the 5\% probability level.

*Maracanã (V): Assai palms of várzea are natives of areas of Amazonian forest flooded seasonally with rains and/or river waters. Várzea is also used to describe the floodplain forests which are flooded; Luís Domingues (IG): Assai palm of igapó are natives of area of forest that remain permanently flooded after the floods with the rains and/or waters of the rivers; Luís Domingues (TF): Assai palm of terra firme refers to lower elevation Amazonian rain forest growing on higher, solid ground that does not flood.

$* * \mathrm{~S}_{1}$ : alternative substrate (composed of sand, agricultural soil and cattle manure in the proportion of 2: 2:1), $\mathrm{S}_{2}$ commercial substrate $\left(\right.$ FORTH $^{\circledR}$ composed of pinus bark and ash).

Considering the recalcitrant character of E. oleracea seeds, the moisture levels were 21.57, 25.7 and $28 \%$, respectively, for the seeds of the igapó, terra firme and várzea assai palms. It is important to highlight the controversy, based on the reports of Martins et al. (2009), of the presence of lots with high water content and low emergence of seedlings. That was the case observed for Luís Domingues (TF) assai seeds, with values between 43.27 and $44.71 \%$. In other hand, it was observed seed with a relatively low water and high emergence seedlings, similar to the results for assai Luís Domingues (IG), with values between 56.82 and 61.12\% (Table 2). Probably, these results can be attributed to other causes related to the low quality of the seeds, which is not determined by the degree of humidity. 
Among the factors affecting seed quality are the environmental conditions during their formation, from flowering to harvesting, such as temperature, water availability, presence of organic matter, nutrients and the occurrence of diseases and pests (Marcos Filho, 2015). It should be noted that assai palm seed lots from this study were harvested in different environments and that assai palm tree plantations cultivated on land with plots that are absent from management, such as slabs of fertilizer and defensive use, may explain the lower physiological potential of its seeds. This fact could be verified for the seed lot of Luís Domingues (TF), harvested in plants cultivated in Agroforestry System (AFS) with 'cupuaçu' (T. grandiflorum).

During the germination of the seeds until the seedling emerges from the substrate, carbon mobilization can occur in the form of carbohydrates or lipids, with starch being one of the essential storage polysaccharides. Therefore, from the results obtained in this study, it can be assumed that the concentration of reserves is greater in the seeds of E. oleracea collected in flooded areas than in the land areas. Gonçalves et al. (2010) report these evidences, as a possible evolutionary adaptation in the use of the organic matter by E. oleracea palm trees that grow in flooded habitat, because they accumulate more carbohydrates in the seeds. In addition to the physiological activities that vary, initial seed quality, substrate structure, water retention capacity and soil aeration also contribute to increased seedling emergence uniformity and speed (Melo et al., 2017).

The results obtained in this study are consistent with those reported by Martins-Corder and Saldanha (2006), who verified the efficiency of the mixture composed by humus and agricultural soil as a substrate to evaluate the emergence of seedlings of different E. edulis progenies. Similarly, Brahm et al. (2013), found that the use of alternative substrates composed of agricultural soil combined with charcoal rice husk or in natura rice husk were adequate, when compared to the commercial substrate Plantmax ${ }^{\circledR}$ for the uniformity and speed of growth of $E$. edulis and Roystonea regia (Kunth).

From the results of Tables 3 and 4, it was verified that there was a significant interaction between Tukey's test at the $5 \%$ probability level between assai seed lots and substrates, for the evaluated characteristics, except for the root length and dry mass of the roots seedlings. The highest lengths of the aerial part (AL) were verified in Luís Domingues (IG) and Luís Domingues (TF) assai seedlings, in the alternative substrate $\left(\mathrm{S}_{1}\right)$, with values of 15.77 and $16.15 \mathrm{~cm}$ seedling ${ }^{-1}$. Besides, the values above mentioned did not differ from the average of $17.62 \mathrm{~cm}$ seedling $^{-1}$, obtained for this same parameter by seedlings from Maracanã (V) assai seeds on commercial substrate $\left(\mathrm{S}_{2}\right)$ (Table 3).

Table 3. Length of the Aerial Part (AL) and Roots Length (RL) of E. oleracea seedlings, from seeds of three ecotypes São Luis, MA, Brazil, 2018 under two different substrates

\begin{tabular}{llllll}
\hline \multirow{2}{*}{ Ecotypes } & \multicolumn{2}{c}{$\mathrm{AL}$} & & \multicolumn{2}{c}{$\mathrm{RL}$} \\
\cline { 2 - 3 } \cline { 5 - 6 } & $* * \mathrm{~S}_{1}$ & $\mathrm{~S}_{2}$ & & $\mathrm{~S}_{1}$ & $\mathrm{~S}_{2}$ \\
\hline Luís Domingues (IG) & $15.77 \mathrm{aA}$ & $9.63 \mathrm{bB}$ & & $9.94 \mathrm{aA}$ & $8.94 \mathrm{aA}$ \\
Maracanã (V) & $11.06 \mathrm{bB}$ & $17.62 \mathrm{aA}$ & & $8.15 \mathrm{aA}$ & $8.83 \mathrm{aA}$ \\
Luís Domingues (TF) & $16.15 \mathrm{aA}$ & $9.74 \mathrm{bB}$ & & $8.83 \mathrm{aA}$ & $9.36 \mathrm{aA}$ \\
\cline { 1 - 2 } C.V. (\%) & 10.69 & & 11.26 & \\
\hline
\end{tabular}

Note. Means followed by the same lowercase letters in the column and upper case in the row do not differ from each other by the Tukey test at the $5 \%$ probability level.

*Maracanã (V): Assai palms of várzea are natives of areas of Amazonian forest flooded seasonally with rains and/or river waters. Várzea is also used to describe the flood plain forests which are flooded; Luís Domingues (IG): Assai palm of igapó are natives of area of forest that remain permanently flooded after the floods with the rains and/or waters of the rivers; Luís Domingues (TF): Assai palm of terra firme refers to lower elevation Amazonian rain forest growing on higher, solid ground that does not flood.

** $\mathrm{S}_{1}$ : alternative substrate (composed of sand, agricultural soil and cattle manure in the proportion of 2:2:1), $\mathrm{S}_{2}$ : commercial substrate $\left(\right.$ FORTH ${ }^{\circledR}$ composed of pinus bark and ash).

For the primary root (Table 4), the greatest dry matter content of the seedlings varied between 0.95 and $1.82 \mathrm{~g}$ seedlings ${ }^{-1}$, being these values statistically similar, regardless of the ecotype and substrate evaluated, excerpt for the dry mass of the seedlings roots of assai Luís Domingues (IG) with development in alternative substrate $\left(\mathrm{S}_{1}\right)$ (Table 4). Similar results were reported by Brahm et al. (2013), studying the formation of biomass in seedlings of 
R. regia, verified a higher amount of roots formed in the experimental plots emerged in an alternative substrate composed of agricultural soil and carbonized rice husk.

Table 4. Aerial Part Dry Mass (APDM) and Root Dry Mass (RDM) of E. oleracea seedlings, from seeds of three ecotypes. São Luis, MA, Brazil, 2018 under two different substrates

\begin{tabular}{llllll}
\hline \multirow{2}{*}{$*$ Ecotypes } & \multicolumn{2}{c}{ APDM } & & \multicolumn{2}{c}{ RDM } \\
\cline { 2 - 3 } \cline { 5 - 6 } & $* * \mathrm{~S}_{1}$ & $\mathrm{~S}_{2}$ & & $\mathrm{~S}_{1}$ & $\mathrm{~S}_{2}$ \\
\hline Luís Domingues (IG) & $1.45 \mathrm{bA}$ & $1.06 \mathrm{aA}$ & & $0.40 \mathrm{aA}$ & $0.41 \mathrm{aA}$ \\
Maracanã (V) & $1.82 \mathrm{aA}$ & $0.95 \mathrm{aA}$ & & $0.36 \mathrm{aA}$ & $0.36 \mathrm{aA}$ \\
Luís Domingues (TF) & $1.80 \mathrm{aA}$ & $0.97 \mathrm{aA}$ & & $0.37 \mathrm{aA}$ & $0.33 \mathrm{aA}$ \\
\hline C.V. (\%) & 10.67 & & 10.24 & \\
\hline
\end{tabular}

Note. Means followed by the same lowercase letters in the column and upper case in the row do not differ from each other by the Tukey test at the $5 \%$ probability level.

*Maracanã (V): Assai palms of várzea are natives of areas of Amazonian forest flooded seasonally with rains and/or river waters. Várzea is also used to describe the flood plain forests which are flooded; Luís Domingues (IG): Assai palm of igapó are natives of area of forest that remain permanently flooded after the floods with the rains and/or waters of the rivers; Luís Domingues (TF): Assai palm of terra firme refers to lower elevation Amazonian rain forest growing on higher, solid ground that does not flood.

** $\mathrm{S}_{1}$ : alternative substrate (composed of sand, agricultural soil and cattle manure in the proportion of 2:2:1), $\mathrm{S}_{2}$ : commercial substrate $\left(\mathrm{FORTH}^{\circledR}\right.$ composed of pinus bark and ash).

Martins et al. (2013), studying the development of palm trees seedlings, such as A. cunninghamiana, found that certain progenies can express a larger growth dimension in length and diameter of the colon. These characteristics confer to the seedling greater capacity of competition and establishment in environment with natural conditions, allowing the survival of these ecotypes. On the other hand, according to the reports of Beckmann et al. (2012) palm seeds adapt easily to substrates with good water retention and aeration under greenhouse conditions, which may favor root growth and seedling development of these species. This evidence may be used to explain the statistical similarity found for results related to the E. oleracea length and dry mass rootlets obtained in this study (Tables 3 and 4).

It is considered more vigorous seeds that give rise to seedlings with higher values of length and, especially of dry mass, in a same period of time (Marcos Filho, 2015). From the dry matter content that can be accurately correlated with the transfer of seed reserves to the embryonic axis (Nakagawa 1999), the high-vigor lots can be selected. Thus, seedlings that produce vigorous seeds, with a good amount of reserves, are usually used in genetic improvement programs of palm trees, whose cross-breeding with this characteristic allows the obtaining of populations with this genetic gain (Rivas et al., 2012).

The management of E. oleracea ecotypes in the Amazonian biome is still the most widely used alternative, promoting the maintenance of sustainable resources over time, since it allows the restoration of the individuals that are harvested (Rivas et al., 2012). However, farmers have not demonstrated that they are interested in this management, especially because under natural conditions in the forest the seeds of assai palm can take from one to eleven months to germinate in the soil (Gonçalves et al., 2010). In this sense, genetic diversity and genotype-environment interaction must be researched, among other topics, because characteristics such as seed size, type and quantity of reserves and physiological potential, vary according to the matrices used, soil fertility conditions, the climate of the place of its production and the time witch the seeds were harvested (Martins et al., 2007).

\section{Conclusion}

The assai palm from ecotypes of the Luís Domingues (IG) and Maracanã (V), native to the igapó and várzea areas, respectively, have high physiological potentials of their seeds and are indicated for selection of assai palm's mother plants. For the emergence and initial growth of seedlings of these ecotypes, are recommended the alternative substrate (composed of sand, agricultural soil and cattle manure in a proportion of 2:2:1) and, commercial substrate (FORTH ${ }^{\circledR}$ compound of pinus and gray bark). 


\section{References}

Barros, L., Calhelha, R. C., Queiroz, M. J. R. P., Santos-Buelga, C., Santos, E. A., Regis, W. C. B., \& Ferreira, I. C. F. R. (2015). The powerful in vitro bioactivity of Euterpe oleracea Mart. seeds and related phenolic compounds. Industrial Crops and Products, 76(4), 318-322. https://doi.org/10.1016/j.indcrop.2015.05.086

Barroso, R. M., Reis, A., \& Hanazaki, N. (2010). Ethnoecology and ethnobotany of the juçara palm (Euterpe edulis Martius) in "quilombola" communities of the Ribeira River Valley, São Paulo. Acta Botanica Brasilica, 24(2), 518-528. https://doi.org/10.1590/S0102-33062010000200022

Beckmann, C. M. Z., Pivetta, K. F. L., Iha, L. L., \& Takane, R. J. (2012). Temperature, mechanical scarification and substrate on seed germination of 'juçara' and 'açaí' palm. Revista Brasileira de Ciências Agrárias, 7(4), 569-573. https://doi.org/10.5039/agraria.v7i4a1684

Brahm, R. Ü., Medeiros, C. A. B., Cardoso, J. H., \& Reisser Junior, C. (2013). Evaluation of the Effect of Different Substrates on the Development of Euterpe edulis (Mart.) the Roystonea regia (Kunth). Revista Brasileira de Agroecologia, 8(2), 148-160. Retrieved from http://revistas.abaagroecologia.org.br/index.php/ rbagroecologia/article/view/10033

Brasil, Ministério da Agricultura, Pecuária e Abastecimento. (2009). Regras para Análise de Sementes (p. 395). Secretaria de Defesa Agropecuária. Brasília: MAPA/ACS.

Garzón, G. A., Narváez-Cuenca C. E., Vincken, J. P., \& Gruppen, H. (2017). Polyphenolic composition and antioxidant activity of açai (Euterpe oleracea Mart.) from Colombia. Food Chemistry, 217(2), 364-372. https://doi.org/10.1016/j.foodchem.2016.08.107

Gonçalves, J. C., Lima, R. B. S., Fernandes, A. V., Borges, E. E. L., \& Buckeridge, M. S. (2010). Physiological and biochemical characterization of the assai palm (Euterpe oleracea Mart.) during seed germination and seedling growth under aerobic and anaerobic conditions. Revista Árvore, 34(6), 1045-1053. https://doi.org/ $10.1590 / \mathrm{S} 0100-67622010000600010$

Maguire, J. D. (1962). Speed of germination-aid selection evolution for seedling emergence and vigor. Crop Science, 2(2), 176-177. Retrieved from https://dl.sciencesocieties.org/publications/cs/abstracts/2/2/CS0020 020176/preview/pdf

Marcos Filho, J. (2015). Seed vigor testing: an overview of the past, present and future perspective. Scientia Agricola, 72(4), 363-374. https://doi.org/10.1590/0103-9016-2015-0007

Martins, C. C., Bovi, M. L. A., Mori, E. S., \& Nakagawa, J. (2007). Isoenzymes in the differentiation of three Euterpe species. Revista Árvore, 31(1), 51-57. https://doi.org/10.1590/S0100-67622007000100007

Martins, C. C., Bovi, M. L. A., Oliveira, S. S. C., \& Vieira, R. D. (2013). Emergence and seedling growth of Archontophoenix cunninghamiana H. Wendl. \& Drude seeds from different mother plants. Ciência Rural, 43(6), 1006-1011. https://doi.org/10.1590/S0103-84782013005000051

Martins, C. C., Nakagawa, J., \& Bovi, M. L. A. B. (2009). Assai seeds physiological quality evaluation. Revista Brasileira de Fruticultura, 31(1), 231-235. https://doi.org/10.1590/S0100-29452009000100032

Martins-Corder, M. P., \& Saldanha, C. W. (2006). Seed germination and seedling growth of diferentes progenies of Euterpe edulis Mart.. Revista Árvore, 30(5), 693-699. https://doi.org/10.1590/S0100-67622006000 500002

Melo, P. A. F. R., Cavalcanti, M. I. P., Alves, E. U., Martins, C. C., \& Araújo, L. R. (2017). Substrates and temperatures in the germination of Eriotheca gracilipes seeds. Revista Ciência Agronômica, 48(2), 303-309. https://doi.org/10.5935/1806-6690.20170035

Nakagawa, J. (1999). Testes de vigor baseados no desempenho das plântulas. In F. C. Krzyzanoski, R. D. Vieira, J. B. França Neto (Eds.), Vigor de sementes: conceitos e testes (Cap. 2, pp. 1-24). Londrina: ABRATES.

Oliveira, L. C., Oliveira, M. S., Davide, L. C., \& Torres, G. A. (2016). Karyotype and genome size in Euterpe oleraceae Mart. (Arecaceae) species. Comparative Cytogenetics, 10(1), 17-25. https://doi.org/10.3897/ CompCytogen.v10i1.5522

Paniagua-Zambrana, N., Bussmann, R. W., \& Macía, M. J. (2017). The socioeconomic context of the use of Euterpe precatoria Mart. and E. oleracea Mart. in Bolivia and Peru. Journal of Ethnobiology and Ethnomedicine, 32(3), 1-17. https://doi.org/10.1186/s13002-017-0160-0 
Ramos, S. L. F., Macêdo, J. L. V., Martins, C. C., Lopes, R., \& Lopes, M. T. G. (2011). Pre-germination treatments and origin of tucumã-do-amazonas seeds in the production of seedlings. Revista Brasileira de Fruticultura, 33(3), 962-969. https://doi.org/10.1590/S0100-29452011000300033

Rivas, M., Barbieri, R. L., \& Maia, C. L. (2012). Plant breeding and in situ utilization of palm trees. Ciência Rural, 42(2), 261-269. https://doi.org/10.1590/S0103-84782012000200013

Wycoff, W., Luo, R., Schauss, A. G., Neal-Kababick, J., Sabaa-Srur, A. O. O., Maia, J. G. S., ... Smith, R. E. (2015). Chemical and nutritional analysis of seeds from purple and white açaí (Euterpe oleracea Mart.). Journal of Food Composition and Analysis, 41(4), 181-187. https://doi.org/10.1016/j.jfca.2015.01.021

\section{Copyrights}

Copyright for this article is retained by the author(s), with first publication rights granted to the journal.

This is an open-access article distributed under the terms and conditions of the Creative Commons Attribution license (http://creativecommons.org/licenses/by/4.0/). 